\title{
Influenza Virus and Glycemic Variability in Diabetes: A Killer Combination?
}

\author{
Katina D. Hulme ${ }^{1}$, Linda A. Gallo ${ }^{1,2+}$ and Kirsty R. Short ${ }^{1,3 *+}$ \\ ${ }^{1}$ School of Biomedical Sciences, The University of Queensland, Brisbane, QLD, Australia, ${ }^{2}$ Mater Research Institute, \\ The University of Queensland, Brisbane, QLD, Australia, ${ }^{3}$ Australian Infectious Diseases Research Centre, The University of \\ Queensland, Brisbane, QLD, Australia
}

Following the $2009 \mathrm{H} 1 \mathrm{~N} 1$ influenza virus pandemic, numerous studies identified the striking link between diabetes mellitus and influenza disease severity. Typically, influenza virus is a self-limiting infection but in individuals who have a pre-existing chronic illness, such as diabetes mellitus, severe influenza can develop. Here, we discuss the latest clinical and experimental evidence for the role of diabetes in predisposing the host to severe influenza. We explore the possible mechanisms that underlie this synergy

OPEN ACCESS

Edited by:

Aeron Hurt,

WHO Collaborating Centre for Reference and Research on

Influenza, Australia

Reviewed by:

Paul Horwood

Pasteur Institute in Cambodia,

Cambodia

Julie McAuley,

University of Melbourne, Australia

*Correspondence:

Kirsty R. Short

k.shor@@uq.edu.au

tThese authors have contributed equally to this study.

Specialty section: This article was submitted to

Virology,

a section of the journa

Frontiers in Microbiology

Received: 07 March 2017 Accepted: 27 April 2017 Published: 22 May 2017

Citation: Hulme KD, Gallo LA and Short KR (2017) Influenza Virus and Glycemic

Variability in Diabetes: A Killer Combination? Front. Microbiol. 8:861. doi: 10.3389/fmicb.2017.00861 and highlight the, as yet, unexplored role that blood glucose oscillations may play in disease development. Diabetes is one of the world's fastest growing chronic diseases and influenza virus represents a constant and pervasive threat to human health. It is therefore imperative that we understand how diabetes increases influenza severity in order to mitigate the burden of future influenza epidemics and pandemics.

Keywords: influenza, diabetes, glucose, hyperglycemia, glycemic oscillations

\section{INTRODUCTION}

Every year, approximately $5-15 \%$ of the world's population are infected with influenza virus (Shirey et al., 2013). Of the three types of influenza virus (A, B, and C), influenza $A$ virus is the most common cause of respiratory illnesses in humans. Influenza A virus typically causes an acute and self-limiting infection characterized by symptoms such as myalgia, fever, and a dry cough. However, in patients with one or more underlying medical conditions, influenza A virus can cause severe, and even fatal, disease (Short et al., 2015). Influenza thus represents a significant healthcare challenge for the 21st century, where the majority of people have more than one medical ailment (Vos et al., 2015). This interaction between chronic disease and influenza was particularly evident after the 2009 H1N1 influenza pandemic (Kumar et al., 2009). Specifically, this pandemic highlighted that people with diabetes suffered from more severe influenza than people with no underlying medical condition (Allard et al., 2010; Wilking et al., 2010). Here, we review the currently available literature on the role of diabetes in the pathogenesis of influenza virus. We further highlight the specific roles that high, and/or oscillating, blood glucose levels may play in the severity of influenza virus.

\section{DIABETES MELLITUS AND ITS VASCULAR COMPLICATIONS}

Diabetes mellitus affects 415 million people worldwide and this figure is projected to increase to 642 million by the year 2040 (International Diabetes Federation, 2015). Diabetes is characterized by chronic hyperglycemia and is classified into two main types. Type 1 diabetes accounts for 
approximately $10 \%$ of all cases and is most commonly caused by an autoimmune condition affecting insulin production. In contrast, type 2 diabetes accounts for approximately $85-90 \%$ of cases and is characterized by insulin resistance and compromised insulin secretory capacity. All individuals with diabetes have an increased risk of developing a number of serious complications. Diabetes is a leading cause of blindness, limb amputations, endstage kidney failure, and cardiovascular disease (The Emerging Risk Factors Collaboration, 2011). Chronic hyperglycemia is thought to underlie the development of complications and, as such, a primary aim in the management of diabetes is to improve blood glucose control (Gallo et al., 2015). Blood glucose control is typically assessed by measuring a patient's HbAlc. The term HbAlc refers to glycated hemoglobin, i.e., when hemoglobin joins with glucose and becomes 'glycated.' The average lifespan of red blood cells is approximately $2-3$ months, meaning that HbAlc provides an estimate of long-term blood glucose control. Interestingly, however, there is no guarantee that achieving nearnormal HbA1c levels (HbA1c < 7\%), particularly in patients with long-standing type 2 diabetes, will prevent the onset and progression of vascular complications. Using traditional therapies, such as metformin, sulphonylureas and insulin, nearnormal HbA1c levels were achieved in numerous trials but mortality from cardiovascular disease was either not affected (The U.K. Prospective Diabetes Study Group, 1998; The Advance Collaboration group, 2008; Duckworth et al., 2009) or increased (The Action to Control Cardiovascular Risk in Diabetes Study Group et al., 2008). In the latter study, the trial was prematurely stopped due to a significant increase in short-term mortality following intensive glucose lowering (The Action to Control Cardiovascular Risk in Diabetes Study Group et al., 2008). The lack of a definitive conclusion in this field has dampened clinical urgency to normalize $\mathrm{HbA1}$ c levels and suggests that other factors may contribute to the development of diabetic complications.

\section{INFLUENZA VIRUS IN DIABETES MELLITUS}

Prior to the $2009 \mathrm{H} 1 \mathrm{~N} 1$ pandemic, several studies had already suggested that diabetes enhanced the severity of influenza (Diepersloot et al., 1987; Valdez et al., 1999). Valdez et al. (1999) showed that from 1986 to 1989, people with diabetes were more likely to have pneumonia and influenza recorded on their death certificate than people without diabetes. However, the most extensive body of evidence regarding this relationship emerged following the first influenza pandemic of the 21st century: the 2009 H1N1 pandemic. Numerous clinical studies suggested that people with diabetes were a key susceptibility group for severe H1N1 infections (see Table 1). For example, in Canada, diabetes tripled the risk of hospitalization after infection with the 2009 $\mathrm{H} 1 \mathrm{~N} 1$ virus and quadrupled the risk of admission to the intensive care unit (Allard et al., 2010). Similarly, in Germany, diabetes doubled the risk of a fatal outcome after infection with the 2009 virus (Wilking et al., 2010). Whilst the majority of clinical studies suggest a role for diabetes in increasing influenza severity, this synergism was not observed in all studies (see Table 1).
Taken together, these data suggest that the relationship between diabetes and influenza may vary depending on the diabetic patient population in question. It is also important to note that many patients with diabetes have various other conditions that can increase (or decrease) the severity of influenza. For example, approximately $90 \%$ of patients living with type 2 diabetes are overweight, and obesity is an independent risk factor for severe influenza (Morgan et al., 2010). Adjusting clinical analyses for the presence of these other illnesses has yielded contradictory results (see Table 1), highlighting the need for further research in this area. Nevertheless, consistent with the majority of clinical observations, murine models demonstrate that diabetes increases susceptibility to severe infections with both seasonal and highly pathogenic influenza virus strains (see Table 2).

\section{A ROLE FOR HYPERGLYCEMIA}

At present, the mechanisms by which diabetes can increase the severity of influenza remain unclear. There is a growing body of evidence that hyperglycemia can increase the incidence and severity of bacterial infections. For example, diabetic patients with an HbAlc level $>7 \%$ had a three times increased risk of active tuberculosis compared to those with an HbA1c level < 7\% (Leung et al., 2008). Similarly, diabetic patients with hyperglycemia ( $>7 \% \mathrm{HbA1c}$ ) were more likely to develop Klebsiella pneumoniae liver abscess than diabetic patients with controlled glycaemia (Lin et al., 2013). It has also been reported that individuals with diabetes are more likely to suffer from infection-related mortality following a kidney allograft than non-diabetic patients (Hayer et al., 2014). However, in a recent systematic review of a range of surgical specialities, the relationship between preoperative HbA1c levels and postoperative complications, including mortality from infection, was less convincing (Rollins et al., 2016). The authors noted that their retrospective analyses contained heterogenous datasets of small sample sizes and that further research, specifically dedicated to addressing this topic, is warranted (Rollins et al., 2016).

With regards to respiratory tract infections, Rayfield et al. (1982) noted a striking positive correlation with the mean plasma glucose levels in patients with diabetes. These findings may reflect, in part, the immunosuppressive effects of hyperglycemia. Hyperglycemia can reduce neutrophil degranulation (Stegenga et al., 2008), impair complement activation (Ilyas et al., 2011) and impair phagocytosis (Alexiewicz et al., 1995) - all of which can increase the severity of bacterial infections as well as viral infections such as influenza. However, to date, there have been only limited experimental studies directly addressing the role of hyperglycemia in the pathogenesis of influenza virus.

Elevated blood glucose levels can directly increase glucose concentrations in airway secretions (Philips et al., 2003). In vitro exposure of pulmonary epithelial cells to elevated glucose concentrations significantly increased influenza virus infection and replication (Kohio and Adamson, 2013), suggesting that hyperglycemia may increase viral replication in vivo. Elevated 


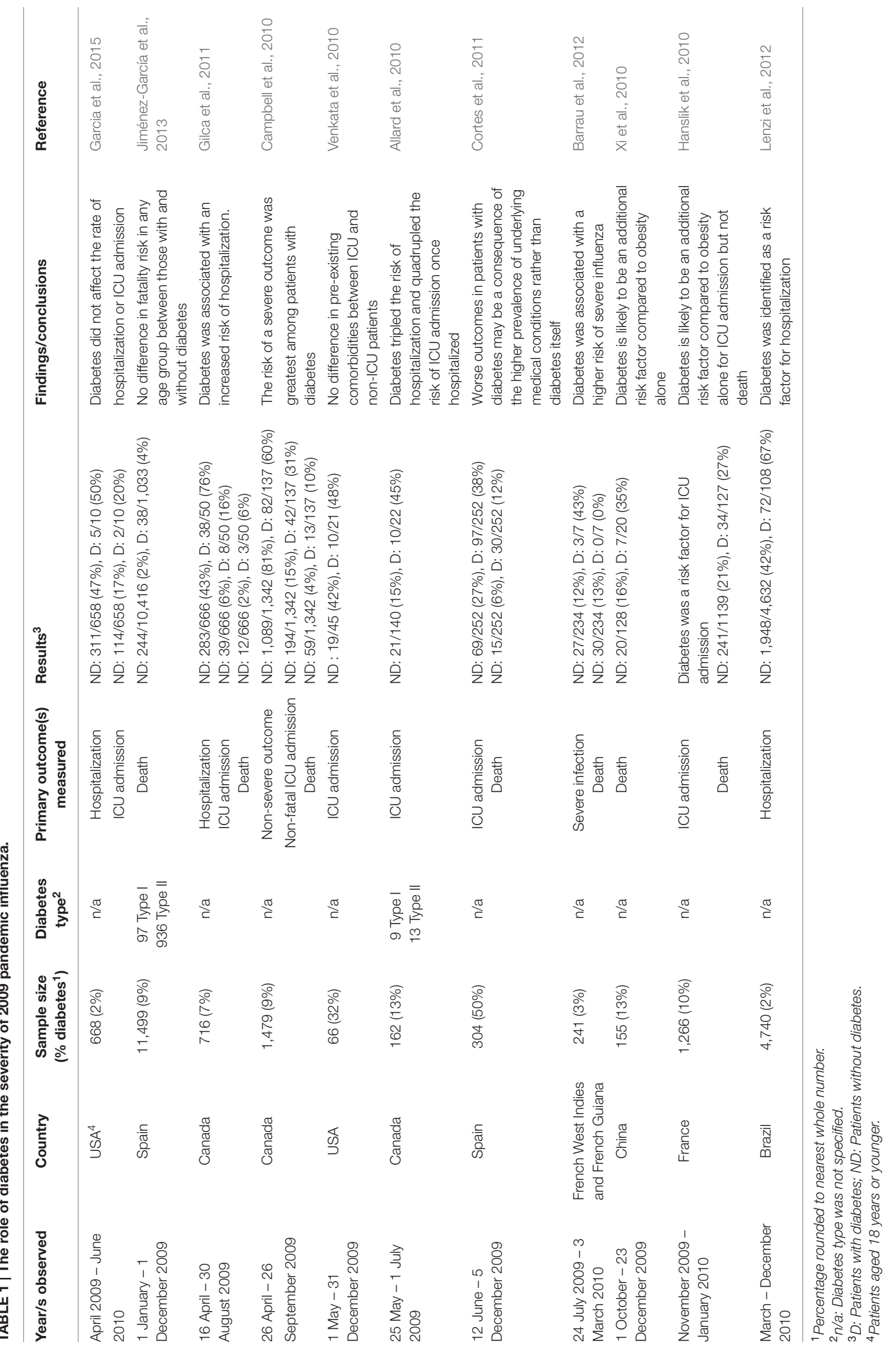


TABLE 2 | Animal models of diabetes and influenza.

\begin{tabular}{|c|c|c|c|c|c|}
\hline Mouse model & $\begin{array}{l}\text { Diabetes type } \\
\text { modeled }\end{array}$ & $\begin{array}{l}\text { Influenza A } \\
\text { virus subtype }\end{array}$ & $\begin{array}{l}\text { Measure of } \\
\text { disease severity }\end{array}$ & Findings & Reference \\
\hline $\begin{array}{l}\text { STZ-induced diabetes in } \\
\text { BALB/c mice }\end{array}$ & I & $\mathrm{H} 1 \mathrm{~N} 1$ & $\begin{array}{l}\text { Lung viral titers } \\
\text { Lethal dose } 50\end{array}$ & $\begin{array}{l}\text { Diabetic mice had increased influenza virus } \\
\text { titers and a lower lethal dose } 50 \text { compared } \\
\text { to non-diabetic mice. }\end{array}$ & Zhu et al., 2005 \\
\hline $\begin{array}{l}\text { STZ-induced diabetes in } \\
\text { BALB/c mice }\end{array}$ & I & $\mathrm{H} 5 \mathrm{~N} 1$ & $\begin{array}{l}\text { Lung viral titers } \\
\text { Lethal dose } 50\end{array}$ & $\begin{array}{l}\text { Diabetic mice had increased influenza virus } \\
\text { titers, a lower lethal dose } 50 \text { and a more } \\
\text { persistent viral infection compared to } \\
\text { non-diabetic mice. }\end{array}$ & Wu et al., 2010 \\
\hline $\begin{array}{l}\text { RIP-K } K^{b} \text { transgenic diabetic } \\
\text { mice }\end{array}$ & I & H3N2 & $\begin{array}{l}\text { Lung viral titers } \\
\text { Weight loss }\end{array}$ & $\begin{array}{l}\text { There was a significant correlation between } \\
\text { blood glucose levels and influenza virus } \\
\text { titers in diabetic mice. Diabetic mice had } \\
\text { increased influenza virus titers but no } \\
\text { difference in weight loss compared to } \\
\text { non-diabetic mice. }\end{array}$ & Reading et al., 1998 \\
\hline $\begin{array}{l}\text { BKS.Cg-+Leprdb/+Leprdb/Jcl } \\
\text { (diabetic mice) }\end{array}$ & $\|$ & $\mathrm{H} 1 \mathrm{~N} 1$ & $\begin{array}{l}\text { Lethal dose } 50 \\
\text { Death }\end{array}$ & $\begin{array}{l}\text { Diabetic mice had a lower lethal dose } 50 \\
\text { and a higher mortality rate compared to } \\
\text { non-diabetic mice. }\end{array}$ & Ito et al., 2015 \\
\hline
\end{tabular}

glucose levels may also serve to suppress the anti-viral immune response (Reading et al., 1998). In a mouse model of type I diabetes, susceptibility to influenza was associated with a reduction in the anti-viral activity of collectins (Reading et al., 1998). This immunosuppression was driven by hyperglycemia as disease susceptibility could be reversed with insulin treatment (Reading et al., 1998). These findings are consistent with studies of patients infected with highly pathogenic avian influenza, whereby hyperglycemia was associated with a fatal outcome (Wiwanitkit, 2008). Interestingly, in a mouse model of type II diabetes, susceptibility to influenza was associated with an impairment in the recruitment of macrophages to the lung (Ito et al., 2015). However, whether this phenotype was driven by hyperglycemia or other physiological changes associated with diabetes remains to be determined. Hyperglycemia may also affect pulmonary function such that influenza virus-induced respiratory dysfunction is exacerbated in patients with diabetes. In animal models of disease, diabetes is associated with numerous structural changes to the lung including augmented permeability of the vasculature and a collapsed alveolar epithelium (Popov and Simionescu, 1997). In patients with diabetes, there is also a significant reduction in forced vital capacity (FVC) and forced expiratory volume in one second (FEV1), and this impaired pulmonary function is significantly associated with raised plasma glucose concentration (Lange et al., 1989; Yeh et al., 2008). Finally, it is important to recognize that during influenza virus pandemics of the last century (including the $2009 \mathrm{H} 1 \mathrm{~N} 1$ pandemic) the majority of fatalities were the result of secondary bacterial infections, rather than primary viral pneumonia (Short et al., 2012). Elevated airway glucose concentrations can increase the replication of respiratory bacterial pathogens (Garnett et al., 2013), suggesting that patients with diabetes may have increased bacterial outgrowth after an influenza virus infection. However, to the best of our knowledge, there have been no large-scale clinical studies investigating the association between influenza severity (and the acquisition or development of any associated secondary bacterial infection) and hyperglycemia in patients with diabetes. Thus, at present, the role of hyperglycemia in the pathogenesis of influenza virus remains unclear.

\section{A ROLE FOR GLYCEMIC OSCILLATIONS}

In the context of vascular complications of diabetes (e.g., cardiovascular disease), there is a growing body of evidence indicating that glucose variability is an important contributing factor to disease development (Hirakawa et al., 2014). In healthy individuals, blood glucose levels are kept within a narrow range of 4.4-6.7 mmol/L, including small and short-lived post-prandial peaks (Saisho, 2014). In the setting of impaired glucose tolerance, glucose fluctuations become greater and more frequent (Bonora and Muggeo, 2001). Blood glucose variability generally refers to hour-to-hour or day-to-day oscillations, but may also refer to month-to-month or even year-to-year changes. Glycemic variability is induced by many different factors including consuming a meal, changes in exercise, weight, medication, diet, and sleep patterns (Davies, 2004). As hyperglycemia is typically measured by a patient's HbAlc, individuals with steady-state and oscillating glucose levels are generally not differentiated in the clinic, making prevalence estimates difficult to obtain. However, it is clear from clinical studies that the extent to which these glucose fluctuations occur differs greatly from patient to patient (Monnier et al., 2006).

There is now a growing body of evidence showing that glycemic oscillations play an important role in endothelial dysfunction, irrespective of HbA1c levels (Risso et al., 2001; Quagliaro et al., 2003; Azuma et al., 2006; Ceriello et al., 2008). For example, patients with type 2 diabetes that had blood glucose levels oscillating between 15 and $5 \mathrm{mmol} / \mathrm{l}$ every $6 \mathrm{~h}$ for $24 \mathrm{~h}$ had a significant increase in endothelial dysfunction relative to diabetic patients exposed to continuous $10 \mathrm{mmol} / \mathrm{l}$ glucose (Ceriello et al., 2008). In vitro, human umbilical endothelial cells (HUVECs) exposed to oscillating glucose have an increased level of apoptosis compared to HUVECs exposed to constant high levels of glucose 
(Quagliaro et al., 2003). Similarly, human endothelial cells exposed to intermittent high glucose had increased expression of ICAM-1, VCAM-1, VEGF, high mobility group box 1 (HMGB1), IL-8, NF- $\kappa \mathrm{B}$ and E-selectin relative to endothelial cells exposed to stable high glucose (Quagliaro et al., 2005; Mudaliar et al., 2014). This is consistent with studies demonstrating increased monocyte adhesion to endothelial cells in rats exposed to glucose fluctuations relative to stable hyperglycemia (Azuma et al., 2006).

Endothelial cells, whilst not the primary target of influenza virus in humans, play an important role in disease pathogenesis (Teijaro et al., 2011; Short et al., 2013, 2014, 2016). During severe influenza virus infection, pulmonary endothelial cells produce cytokines which drive pulmonary lesions and mortality (Teijaro et al., 2011). In addition to mediating cytokine production, endothelial cells also indirectly control the inflammatory response in the lung during influenza virus infection via the expression of adhesion molecules (e.g., E-selectin, P-selectin, ICAM1, and VCAM1) (Short et al., 2014). Overexpression of these adhesion molecules is thought to impair pulmonary function during influenza virus infection by allowing the uncontrolled extravasation of leukocytes in the alveolus (Perrone et al., 2008; Short et al., 2014). These leukocytes can in turn damage the lung and impair respiratory function (Short et al., 2014). Given that glycemic oscillations are known to induce endothelial cytokine production (Quagliaro et al., 2005; Mudaliar et al., 2014) and enhance the expression of endothelial adhesions (Quagliaro et al., 2005; Mudaliar et al., 2014), it is tempting to speculate that glycemic variability augments the severity of influenza, at least in part, via effects on pulmonary endothelial cells.

\section{CONCLUSION AND FUTURE DIRECTIONS}

Diabetes is one of the world's fastest growing chronic diseases, whereby the proportion of adults with diabetes is projected to

\section{REFERENCES}

Alexiewicz, J. M., Kumar, D., Smogorzewski, M., Klin, M., and Massry, S. G. (1995). Polymorphonuclear leukocytes in non-insulin-dependent diabetes mellitus: abnormalities in metabolism and function. Ann. Intern. Med. 123, 919-924. doi: 10.7326/0003-4819-123-12-19951215000004

Allard, R., Leclerc, P., Tremblay, C., and Tannenbaum, T.-N. (2010). Diabetes and the severity of pandemic influenza A (H1N1) infection. Diabetes Care 33, 1491-1493. doi: 10.2337/dc09-2215

Azuma, K., Kawamori, R., Toyofuku, Y., Kitahara, Y., Sato, F., Shimizu, T., et al. (2006). Repetitive fluctuations in blood glucose enhance monocyte adhesion to the endothelium of rat thoracic aorta. Arterioscler. Thromb. Vasc. Biol. 26, 2275-2280. doi: 10.1161/01.ATV.0000239488.05069.03

Barrau, M., Larrieu, S., Cassadou, S., Chappert, J. L., Dussart, P., Najioullah, F., et al. (2012). Hospitalized cases of influenza A(H1N1)pdm09 in the French territories of the Americas, July 2009-March 2010. Pan Am. J. Public Health 32, 124-130. doi: 10.1590/S1020-49892012000800006

Bonora, E., and Muggeo, M. (2001). Postprandial blood glucose as a risk factor for cardiovascular disease in type II diabetes: the epidemiological evidence. Diabetologia 44, 2107-2114. doi: 10.1007/s001250100020 increase from 9 to $10 \%$ by the year 2040 (International Diabetes Federation, 2015). With advancements in awareness, detection, and management of the disease, the average life expectancy of patients with diabetes is increasing (Lutgers et al., 2009; Guja et al., 2011; Huo et al., 2016). Thus, the number of individuals living with long-term complications is enhanced. Given this growing prevalence of diabetes and the increased window of opportunity for influenza virus infection, it is surprising that there are only few published studies in this field. It is therefore imperative that we dedicate research efforts to understanding how diabetes can increase the severity of influenza.

This includes delineating the role of other underlying comorbidities, hyperglycemia and glycemic oscillations in disease development and severity. Moreover, whilst type 1 and type 2 diabetes share a common symptom, i.e., hyperglycemia, they are vastly different in disease pathogenesis and, potentially, in their susceptibility to complications including influenza virus. Therefore, future studies would benefit from studying the development and severity of influenza in both type 1 and type 2 diabetes mellitus. This research will prove vital in mitigating the burden of future influenza epidemics and pandemics.

\section{AUTHOR CONTRIBUTIONS}

Conceived, wrote, and approved the manuscript: KH, LG, and $\mathrm{KS}$.

\section{FUNDING}

KS is supported by a National Health and Medical Research Council of Australia C.J. Martin Early Career Fellowship (APP1054081). LG is supported by a National Health and Medical Research Council of Australia Peter Doherty Early Career Fellowship (APP1089763) and Heart Foundation Postdoctoral Fellowship (Australia).

Campbell, A., Rodin, R., Kropp, R., Mao, Y., Hong, Z., Vachon, J., et al. (2010). Risk of severe outcomes among patients admitted to hospital with pandemic (H1N1) influenza. CMAJ 182, 349-355. doi: 10.1503/cmaj.091823

Ceriello, A., Esposito, K., Piconi, L., Ihnat, M. A., Thorpe, J. E., Testa, R., et al. (2008). Oscillating glucose is more deleterious to endothelial function and oxidative stress than mean glucose in normal and type 2 diabetic patients. Diabetes Metab. Res. Rev. 57, 1349-1354. doi: 10.2337/db08-0063

Cortes, G. M., Sierra Moros, M. J., Santa-Olalla Peralta, P., Hernandez-Barrera, V., Jimenez-Garcia, R., and Pachon, I. (2011). Clinical characteristics and outcomes of diabetes sufferers hospitalized from 2009 pandemic influenza A H1N1 infections. J. Infect. 64, 218-224. doi: 10.1016/j.jinf.2011.11.022

Davies, M. (2004). The reality of glycaemic control in insulin treated diabetes: defining the clinical challenges. Int. J. Obes. Relat. Metab. Disord. 28, S14-S22. doi: 10.1038/sj.ijo.0802745

Diepersloot, R., Bouter, K., Beyer, W., Hoekstra, J., and Masurel, N. (1987). Humoral immune response and delayed type hypersensitivity to influenza vaccine in patients with diabetes mellitus. Diabetologia 30, 397-401. doi: 10. $1007 / \mathrm{BF} 00292541$

Duckworth, W., Abraira, C., Moritz, T., Reda, D., Emanuele, N., Reaven, P. D., et al. (2009). Glucose control and vascular complications in veterans with type 2 diabetes. N. Engl. J. Med. 360, 129-139. doi: 10.1056/NEJMoa0808431 
Gallo, L. A., Wright, E. M., and Vallon, V. (2015). Probing SGLT2 as a therapeutic target for diabetes: basic physiology and consequences. Diabetes Vasc. Dis. Res. 12, 78-89. doi: 10.1177/1479164114561992

Garcia, M. N., Philpott, D. C., Murray, K. O., Ontiveros, A., Revell, P. A., Chandramohan, L., et al. (2015). Clinical predictors of disease severity during the 2009-2010 A(HIN1) influenza virus pandemic in a paediatric population. Epidmiol. Infect. 143, 2939-2949. doi: 10.1017/S0950268815000114

Garnett, J. P., Baker, E. H., Naik, S., Lindsay, J. A., Knight, G. M., Gill, S., et al. (2013). Metformin reduces airway glucose permeability and hyperglycaemiainduced Staphylococcus aureus load independently of effects on blood glucose. Thorax 68, 835-845. doi: 10.1136/thoraxjnl-2012-203178

Gilca, R., De Serres, G., Boulianne, N., Ouhoummane, N., Papenburg, J., DouvilleFradet, M., et al. (2011). Risk factors for hospitalization and severe outcomes of 2009 pandemic H1N1 influenza in Quebec, Canada. Influenza Other Respir. Viruses 5, 247-255. doi: 10.1111/j.1750-2659.2011.00204.x

Guja, C., Ionescu-Tirgoviste, C., Fica, S., Sabau, S., Radu, S., Micu, A., et al. (2011). Improvements in life expectancy in adult type 2 diabetes patients in the last six decades. Diabetes Res. Clin. Pract. 92, 400-404. doi: 10.1016/j.diabres.2011. 03.022

Hanslik, T., Boelle, P. Y., and Flahault, A. (2010). Preliminary estimation of risk factors for admission to intensive care units and for death in patients infected with A(H1N1)2009 influenza virus, France, 2009-2010. PLoS Curr. 2:RRN1150. doi: $10.1371 /$ currents.RRN1150

Hayer, M. K., Farrugia, D., Begaj, I., Ray, D., and Sharif, A. (2014). Infectionrelated mortality is higher for kidney allograft recipients with pretransplant diabetes mellitus. Diabetologia 57, 554-561. doi: 10.1007/s00125-0133124-5

Hirakawa, Y., Arima, H., Zoungas, S., Ninomiya, T., Cooper, M., Hamet, P., et al. (2014). Impact of visit-to-visit glycemic variability on the risk of macrovascular and microvascular events and all-cause mortality in type 2 diabetes: the ADVANCE trial. Diabetes Care 37, 2358-2365. doi: 10.2337/dc14-0199

Huo, L., Harding, J. L., Peeters, A., Shaw, J. E., and Magliano, D. J. (2016). Life expectancy of type 1 diabetic patients during 1997-2010: a national Australian registry-based cohort study. Diabetologia 59, 1177-1185. doi: 10.1007/s00125015-3857-4

Ilyas, R., Wallis, R., Soilleux, E. J., Townsend, P., Zehnder, D., Tan, B. K., et al. (2011). High glucose disrupts oligosaccharide recognition function via competitive inhibition: a potential mechanism for immune dysregulation in diabetes mellitus. Immunobiology 216, 126-131. doi: 10.1016/j.imbio.2010. 06.002

International Diabetes Federation (2015). IDF Diabetes Atlas. Brussels: International Diabetes Federation.

Ito, M., Kubota, H., Takeuchi, T., Qiao, S., Tsurudome, M., Tsumura, H., et al. (2015). Pathogenesis of the influenza virus in diabetes model mice. Br. Microbiol. Res. J. 9, 1-7. doi: 10.9734/BMRJ/2015/18799

Jiménez-García, R., Hernández-Barrera, V., Rodríguez-Rieiro, C., Lopez De Andres, A., De Miguel-Diez, J., Jimenez-Trujillo, I., et al. (2013). Hospitalizations from pandemic Influenza [A(H1N1)pdm09] infections among type 1 and 2 diabetes patients in Spain. Influenza Other Respir. Viruses 7, 439-447. doi: 10.1111/j.1750-2659.2012.00419.x

Kohio, H. P., and Adamson, A. L. (2013). Glycolytic control of vacuolar-type ATPase activity: a mechanism to regulate influenza viral infection. Virology 444, 301-309. doi: 10.1016/j.virol.2013.06.026

Kumar, A., Zarychanski, R., Pinto, R., Cook, D. J., Marshall, J., Lacroix, J., et al. (2009). Critically ill patients with 2009 influenza A (H1N1) infection in Canada. JAMA 302, 1872-1879. doi: 10.1001/jama.2009.1496

Lange, P., Groth, S., Kastrup, J., Mortensen, J., Appleyard, M., Nyboe, J., et al. (1989). Diabetes mellitus, plasma glucose and lung function in a cross-sectional population study. Eur. Respir. J. 2, 14-19.

Lenzi, L., Mello, Â. M., Silva, L. R., Grochocki, M. H., and Pontarolo, R. (2012). Pandemic influenza A (H1N1) 2009: risk factors for hospitalization. J. Bras. Pneumol. 38, 57-65. doi: 10.1590/S1806-37132012000100009

Leung, C. C., Lam, T. H., Chan, W. M., Yew, W. W., Ho, K. S., Leung, G. M., et al. (2008). Diabetic control and risk of tuberculosis: a cohort study. Am. J. Epidemiol. 167, 1486-1494. doi: 10.1093/aje/kwn075

Lin, Y.-T., Wang, F.-D., Wu, P.-F., and Fung, C.-P. (2013). Klebsiella pneumoniae liver abscess in diabetic patients: association of glycemic control with the clinical characteristics. BMC Infect. Dis. 13:56. doi: 10.1186/1471-2334-13-56
Lutgers, H. L., Gerrits, E. G., Sluiter, W. J., Ubink-Veltmaat, L. J., Landman, G. W., Links, T. P., et al. (2009). Life expectancy in a large cohort of type 2 diabetes patients treated in primary care (ZODIAC-10). PLoS ONE 4:e6817. doi: 10.1371/journal.pone.0006817

Monnier, L., Mas, E., Ginet, C., Michel, F., Villon, L., Cristol, J.-P., et al. (2006) Activation of oxidative stress by acute glucose fluctuations compared with sustained chronic hyperglycemia in patients with type 2 diabetes. JAMA 295, 1681-1687. doi: 10.1001/jama.295.14.1681

Morgan, O. W., Bramley, A., Fowlkes, A., Freedman, D. S., Taylor, T. H., Gargiullo, P., et al. (2010). Morbid obesity as a risk factor for hospitalization and death due to 2009 pandemic influenza A (H1N1) disease. PLoS ONE 5:e9694. doi: 10.1371/journal.pone.0009694

Mudaliar, H., Pollock, C., Ma, J., Wu, H., Chadban, S., and Panchapakesan, U. (2014). The role of TLR2 and 4-mediated inflammatory pathways in endothelial cells exposed to high glucose. PLOS ONE 9:e108844. doi: 10.1371/journal.pone. 0108844

Perrone, L. A., Plowden, J. K., García-Sastre, A., Katz, J. M., and Tumpey, T. M. (2008). H5N1 and 1918 pandemic influenza virus infection results in early and excessive infiltration of macrophages and neutrophils in the lungs of mice. PLoS Pathog. 4:e1000115. doi: 10.1371/journal.ppat.1000115

Philips, B. J., Meguer, J.-X., Redman, J., and Baker, E. H. (2003). Factors determining the appearance of glucose in upper and lower respiratory tract secretions. Intensive Care Med. 29, 2204-2210. doi: 10.1007/s00134-003-1961-2

Popov, D., and Simionescu, M. (1997). Alterations of lung structure in experimental diabetes, and diabetes associated with hyperlipidaemia in hamsters. Eur. Respir. J. 10, 1850-1858. doi: 10.1183/09031936.97. 10081850

Quagliaro, L., Piconi, L., Assaloni, R., Da Ros, R., Maier, A., Zuodar, G., et al. (2005). Intermittent high glucose enhances ICAM-1, VCAM-1 and E-selectin expression in human umbilical vein endothelial cells in culture: the distinct role of protein kinase $\mathrm{C}$ and mitochondrial superoxide production. Atherosclerosis 183, 259-267. doi: 10.1016/j.atherosclerosis.2005.03.015

Quagliaro, L., Piconi, L., Assaloni, R., Martinelli, L., Motz, E., and Ceriello, A. (2003). Intermittent high glucose enhances apoptosis related to oxidative stress in human umbilical vein endothelial cells the role of protein kinase $\mathrm{C}$ and NAD (P) H-oxidase activation. Diabetes Metab. Res. Rev. 52, 2795-2804. doi: 10.2337/diabetes.52.11.2795

Rayfield, E. J., Ault, M. J., Keusch, G. T., Brothers, M. J., Nechemias, C., and Smith, H. (1982). Infection and diabetes: the case for glucose control. Am. J. Med. 72, 439-450. doi: 10.1016/0002-9343(82)90511-3

Reading, P. C., Allison, J., Crouch, E. C., and Anders, E. M. (1998). Increased susceptibility of diabetic mice to influenza virus infection: compromise of collectin-mediated host defense of the lung by glucose? J. Virol. 72, 6884-6887.

Risso, A., Mercuri, F., Quagliaro, L., Damante, G., and Ceriello, A. (2001). Intermittent high glucose enhances apoptosis in human umbilical vein endothelial cells in culture. Am. J. Physiol. Endocrinol. Metab. 281, E924-E930.

Rollins, K. E., Varadhan, K. K., Dhatariya, K., and Lobo, D. N. (2016). Systematic review of the impact of $\mathrm{HbAlc}$ on outcomes following surgery in patients with diabetes mellitus. Clin. Nutr. 35, 308-316. doi: 10.1016/j.clnu.2015. 03.007

Saisho, Y. (2014). Glycemic variability and oxidative stress: a link between diabetes and cardiovascular disease? Int. J. Mol. Sci. 15, 18381-18406. doi: 10.3390/ ijms 151018381

Shirey, K. A., Lai, W., Scott, A. J., Lipsky, M., Mistry, P., Pletneva, L. M., et al. (2013). The TLR4 antagonist Eritoran protects mice from lethal influenza infection. Nature 497, 498-502. doi: 10.1038/nature12118

Short, K. R., Habets, M. N., Hermans, P. W., and Diavatopoulos, D. A. (2012). Interactions between Streptococcus pneumoniae and influenza virus: a mutually beneficial relationship? Future Microbiol. 7, 609-624. doi: 10.2217/ fmb. 12.29

Short, K. R., Kasper, J., van der Aa, S., Andeweg, A. C., Zaaraoui-Boutahar, F., Goeijenbier, M., et al. (2016). Influenza virus damages the alveolar barrier by disrupting epithelial cell tight junctions. Eur. Respir. J. 47, 954-966. doi: 10.1183/13993003.01282-2015

Short, K. R., Kroeze, E. J. V., Fouchier, R. A., and Kuiken, T. (2014). Pathogenesis of influenza-induced acute respiratory distress syndrome. Lancet Infect. Dis. 14, 57-69. doi: 10.1016/S1473-3099(13)70286-X 
Short, K. R., Richard, M., Verhagen, J. H., van Riel, D., Schrauwen, E. J., van den Brand, J. M. A., et al. (2015). One health, multiple challenges: the inter-species transmission of influenza A virus. One Health 1, 1-13. doi: 10.1016/j.onehlt. 2015.03.001

Short, K. R., Veldhuis Kroeze, E. J., Reperant, L. A., Richard, M., and Kuiken, T. (2013). Influenza virus and endothelial cells: a species specific relationship. Front. Microbiol. 5:653. doi: 10.3389/fmicb.2014.00653

Stegenga, M. E., van der Crabben, S. N., Blümer, R. M., Levi, M., Meijers, J. C., Serlie, M. J., et al. (2008). Hyperglycemia enhances coagulation and reduces neutrophil degranulation, whereas hyperinsulinemia inhibits fibrinolysis during human endotoxemia. Blood 112, 82-89. doi: 10.1182/blood2007-11-121723

Teijaro, J. R., Walsh, K. B., Cahalan, S., Fremgen, D. M., Roberts, E., Scott, F., et al. (2011). Endothelial cells are central orchestrators of cytokine amplification during influenza virus infection. Cell 146, 980-991. doi: 10.1016/j.cell.2011.08.015

The Action to Control Cardiovascular Risk in Diabetes Study Group, Gerstein, H. C., Miller, M. E., Byington, R. P., Goff, D. C. Jr., Bigger, J. T., et al. (2008). Effects of intensive glucose lowering in type 2 diabetes. N. Engl. J. Med. 358, 2545-2559. doi: 10.1056/NEJMoa0802743

The Advance Collaboration group (2008). Intensive blood glucose control and vascular outcomes in patients with type 2 diabetes. N. Engl. J. Med. 358, 2560-2572. doi: 10.1056/NEJMoa0802987

The Emerging Risk Factors Collaboration (2011). Diabetes mellitus, fasting glucose, and risk of cause-specific death. N. Engl. J. Med. 2011, 829-841. doi: 10.1056/ NEJMoa1008862

The U.K. Prospective Diabetes Study Group (1998). Intensive blood-glucose control with sulphonylureas or insulin compared with conventional treatment and risk of complications in patients with type 2 diabetes (UKPDS 33). Lancet 352, 837-853. doi: 10.1016/S0140-6736(98)07019-6

Valdez, R., Narayan, K., Geiss, L., and Engelgau, M. (1999). Impact of diabetes mellitus on mortality associated with pneumonia and influenza among nonHispanic Black and White US adults. Am. J. Public Health 89, 1715-1721. doi: 10.2105/AJPH.89.11.1715

Venkata, C., Sampathkumar, P., and Afessa, B. (2010). Hospitalized Patients with 2009 H1N1 influenza infection: the mayo clinic experience. Mayo Clin. Proc. 85, 798-805. doi: 10.4065/mcp.2010.0166
Vos, T., Barber, R. M., Bell, B., Bertozzi-Villa, A., Biryukov, S., Bolliger, I., et al. (2015). Global, regional, and national incidence, prevalence, and years lived with disability for 301 acute and chronic diseases and injuries in 188 countries, 1990-2013: a systematic analysis for the Global Burden of Disease Study 2013. Lancet 386, 743-800. doi: 10.1016/S0140-6736(15)60692-4

Wilking, H., Buda, S., von der Lippe, E., Altmann, D., Krause, G., Eckmanns, T., et al. (2010). Mortality of 2009 pandemic influenza A (H1N1) in Germany. Euro Surveill. 15:19741.

Wiwanitkit, V. (2008). Hyperglycemia in the recent reported cases of bird flu infection in Thailand and Vietnam. J. Diabetes Complications 22:76. doi: 10. 1016/j.jdiacomp.2006.05.007

Wu, J., Zhang, F., Fang, F., Chang, H., Wang, F., Yang, Z., et al. (2010). Efficacy of inactivated vaccine against $\mathrm{H} 5 \mathrm{~N} 1$ influenza virus infection in mice with type 1 diabetes. Vaccine 28, 2775-2781. doi: 10.1016/j.vaccine.2010. 01.037

Xi, X., Jiang, L., Xu, Y., Li, A., Duan, J., and Du, B. (2010). Hospitalized adult patients with 2009 influenza $\mathrm{A}(\mathrm{H} 1 \mathrm{~N} 1)$ in Beijing, China: risk factors for hospital mortality. BMC Infect. Dis. 10:256. doi: 10.1186/1471-233410-256

Yeh, H.-C., Punjabi, N. M., Wang, N.-Y., Pankow, J. S., Duncan, B. B., Cox, C. E., et al. (2008). Cross-sectional and prospective study of lung function in adults with type 2 diabetes. Diabetes Care 31, 741-746. doi: 10.2337/dc07-1464

Zhu, Q., Chang, H., Chen, Y., Fang, F., Xue, C., Zhang, F., et al. (2005). Protection of inactivated influenza virus vaccine against lethal influenza virus infection in diabetic mice. Biochem. Biophys. Res. Commun. 329, 87-94. doi: 10.1016/j.bbrc. 2005.01.109

Conflict of Interest Statement: The authors declare that the research was conducted in the absence of any commercial or financial relationships that could be construed as a potential conflict of interest.

Copyright (c) 2017 Hulme, Gallo and Short. This is an open-access article distributed under the terms of the Creative Commons Attribution License (CC BY). The use, distribution or reproduction in other forums is permitted, provided the original author(s) or licensor are credited and that the original publication in this journal is cited, in accordance with accepted academic practice. No use, distribution or reproduction is permitted which does not comply with these terms. 